\section{UNESCO (1972) and Malta (1992) Conventions}

\author{
Willem J. H. Willems
}

ICOMOS International Scientific Committee on Archaeological Heritage Management

(ICAHM), Faculty of Archaeology, Leiden

University, Leiden, Netherlands

\section{Brief Definition of the Topic}

In 1972, UNESCO adopted the Convention Concerning the Protection of the World Cultural and Natural Heritage, a treaty that has become UNESCO's most widely accepted international instrument and was ratified by nearly all its member states. Its purpose is to encourage the identification, protection, and preservation of cultural and natural heritage around the world considered to be of outstanding value to humanity. The Convention (http://whc.unesco.org/) is administered by the World Heritage Committee which consists of 21 elected nations that are party to the Convention.

The Convention names formal advisory bodies to the WH Committee, of which ICOMOS, the International Council on Monuments and Sites, advises on cultural properties and advisor on natural sites is the World Conservation Union. ICOMOS is responsible for the evaluation of nominations of cultural properties made by States Parties against the criteria laid down by the WH Committee. In addition to the basic criterion of "outstanding universal value," as specified in the Convention, these relate to aspects of authenticity, management, and conservation.

World Heritage has become a source of prestige for states and cultural properties on the list are rather strongly biased toward architectural heritage. The list also has an imbalance in that most non-western countries are rather poorly represented. In recent years, attempts are made to remedy such issues. Apart from that, archaeological sites benefit most from a nation's participation in the WH Convention not because some archaeological sites may actually make it to the list, but because the vast majority of such sites, that will never make it to the list, may benefit from the obligations imposed by the treaty, especially article 5 that requests proper management of archaeological heritage.

The Malta Convention (http://conventions. coe.int/Treaty/en/Treaties/Html/143.htm) dates from 1992, when the Council of Europe adopted European Convention on the Protection of the Archaeological Heritage (Revised). The treaty has been ratified by almost all European countries and has become an important international standard.

The convention revises the Convention of London and was drafted as a result of the economic development in Europe in the 1960s and 1970s that caused massive destruction of archaeological resources (Willems 2007). The rescue archaeology in those days was unable to cope with the consequences of rapid spatial development and it was clear that to accomplish a better survival of archaeological resources, archaeology should become part of the planning process. After all, the expensive rescue operations were a direct result of a failure to do so. In addition, it was considered desirable that in the future some of those resources could be preserved in situ because their importance was recognized at an early stage. This changed rescue archaeology into preventive archaeology. Further, it had become an accepted principle to charge the developer with the cost of archaeological work resulting from the development. And finally, it was realized that the public needed to benefit more from the results of archaeological research that was conducted mostly in an academic setting. These are the central principles enshrined in the Convention.

\section{Cross-References}

- European Convention on the Protection of Archaeological Heritage (1992)

- International Council on Monuments and Sites (ICOMOS): Scientific Committees and Relationship to UNESCO

- UNESCO World Heritage Convention (1972) 


\section{References}

WILLEMS, W.J.H.2007. The work of making Malta: the Council of Europe's archaeology and planning committee 1988-1996. European Journal of Archaeology 10: $57-71$.

\section{UNESCO World Heritage Convention (1972)}

\author{
Sophia Labadi \\ Centre for Heritage, University of Kent, \\ Canterbury, Kent, UK \\ Courbevoie, France
}

\section{Introduction and Definition}

Economic and environmental pressures led to the adoption in 1972 of the Convention Concerning the Protection of the World Cultural and Natural Heritage (better known as the World Heritage Convention) by UNESCO (the United Nations Educational, Scientific and Cultural Organization). This has become the flagship convention for the conservation and management of heritage sites, with almost universal ratification of 189 countries (as of July 2012), referred to as States Parties. Despite its popularity, this legal instrument is still badly understood.

This entry aims to explain the mechanisms to inscribe sites on the World Heritage List. It then will explain the different efforts undertaken since the early 1990s to widen the framework for implementation of the Convention and to ensure that it encompasses the diversity of the world heritage and not only European sites. The second part presents the failures and issues of the implementation of the Convention, in particular in relation to opening it to the diversity of the heritage of the world. A final section presents potential avenues for the future.

\section{Ensuring the Worldwide Implementation of the World Heritage Convention}

The World Heritage List, the most famous mechanism of the Convention, registers sites deemed to be outstanding universal value. As of July 2012, 962 World Heritage Sites have been inscribed on this list (745 cultural, 188 natural, and 29 mixed properties located in 157 States Parties). Paragraph 49 of the Operational Guidelines defines "outstanding universal value" as "cultural and/or natural significance which is so exceptional as to transcend national boundaries and to be of common importance for present and future generations of all humanity" (UNESCO 2011b). These guidelines provide key information on the implementation of the Convention and are flexible working documents and have been revised more than 15 times in the past 40 years. These guidelines contain the official form that States Parties need to fill to propose sites for inclusion on the World Heritage List. This form which needs to be signed by a representative of the State Party and sent to the UNESCO World Heritage Centre is then assessed by the Advisory Bodies: ICOMOS (the International Council on Monuments and Sites) for cultural heritage sites and IUCN (the International Union for Conservation of Nature) for natural ones. In the case of nominations of "cultural landscapes" (see below), as appropriate, the evaluation is carried out by ICOMOS in consultation with IUCN. For mixed properties (that satisfy a part or the whole of the definitions of both cultural and natural heritage laid out in Articles 1 and 2 of the Convention), the evaluation is carried out jointly by ICOMOS and IUCN. The evaluations by the Advisory Bodies are presented at the annual World Heritage Committee session. This committee, composed of 21 States Parties, decides whether the nominated property should be inscribed on the List, referred (when minor additional information is requested from the State Party) or deferred (when a more substantial revision of the nomination dossier is required).

The ten criteria (six relating primarily to cultural heritage and four to natural heritage) are essential elements to clarify the notion of outstanding universal value. To be included on the World Heritage List, sites have to fulfill at least one of the following ten criteria: 